\title{
サーチエンジン検索結果ページにおける視線情報の分析 Analysis of User Eye Movements during Viewing of Search Engine Results Pages in Web Information Seeking Tasks
}

\author{
高久雅生 ${ }^{* 1}$, 江草由佳 $^{2}$, 寺井仁 ${ }^{3}$, 齋藤ひとみ ${ }^{4}$, \\ 三輪眞木子 ${ }^{5}$, 神門典子 ${ }^{6}$ \\ Masao TAKAKU*1, Yuka EGUSA ${ }^{2}$, Hitoshi TERAI ${ }^{3}$, Hitomi SAITO ${ }^{4}$, \\ Makiko MIWA $^{5}$, Noriko KANDO ${ }^{6}$
}

*1 物質 ·材料研究機構 科学情報室

National Institute for Materials Science

E-mail: TAKAKU.Masao@nims.go.jp

2 国立教育政策研究所 教育研究情報センター

National Institute for Educational Policy Research

E-mail: yuka@nier.go.jp

3 東京電機大学 情報環境学部情報環境学科

Tokyo Denki University

E-mail: terai@sie.dendai.ac.jp

4 愛知教育大学 教育学部

Aichi University of Education

E-mail: hsaito@auecc.aichi-edu.ac.jp

5 放送大学 ICT 活用・遠隔教育センター

The Open University of Japan

E-mail: miwamaki@code.u-air.ac.jp

6 国立情報学研究所 情報社会相関研究系 / 総合研究大学院大学

National Institute of Informatics / Graduate University for Advanced Studies

E-mail: kando@nii.ac.jp

Web 情報探索行動中のサーチェンジン検索結果一覧ページ（以下，SERP と呼ぶ）に対 する行動に着目し，ユーザ実験の方法論により，視線データ，ブラウザログ，事後インタ ビュ一等の情報を包括的に用いて，ユーザ属性，タスク属性，クェリ属性の 3 つの要因と， 眼球運動による視線データとの関連を探った . 分析の結果, SERP における行動の説明変数 としては, 他の要因に比べて Information/Navigational クエリの違いによる効果が最も大き く, SERP への遷移の直接的な原因となるクェリ種別により，ユーザの行動を予測しうる可 能性が示唆された .

We used an eye tracking tool to investigate the effect of user-based, task-based, and querybased properties when people performed information seeking behaviors on the Web on the search engine results pages (SERP). For the analysis of the user experimental data, we integrated information from various sources, including eye tracking data, browser logs, and post-interview data. An analysis of the results indicated that the query type has a dominant effect and implies that SERPs behaviors might be predictable from the type of query.

キーワード：視線情報, 検索結果ページ, 情報探索行動

Keywords: Eye movement data, Search engine results pages, Information seeking behavior 


\section{1 はじめに}

Google に代表されるサーチエンジンが日 常的に使われるようになり，検索エンジン の性能向上と探索行動の支援が，より重要 となってきている．一般の利用者がサーチ エンジンをどのように使っているかは，ロ グ分析やユーザ実験，インタビュー調査な どを通じた研究が行われている [1] .

しかしながら，情報探索の過程で情報を いかにピックアップし，弚の結果として次 にどのような行動が選択されるのかについ て，ユーザ側での自然な情報探索行動全体 にかかわる要因との関係について，包括的 に検討している研究は数少ない．これは， 情報のピックアップを定量的にとらえる方 法が限られていることが挙げられる .

一方, 認知科学における問題解決研究や， ヒューマンコンピュータインタラクション の研究分野においては, 眼球運動データを 用いた分析手法を使って，環境から提供さ れる外的な資源のうち，人がどのような情 報に注目し，また关れらの情報を課題の解 決にどのように利用しているのかについて の研究 [2][3] がある .このような視線デー タは，ユーザが注目する視点をとらえる生 理的側面からのフィードバックであり，近 年には Web ユーザビリティ調査などでの 利用も一般的なものとなっており [4] , 情報 検索研究においても検索アルゴリズムへの フィードバック [5][6] といった応用例はあ るものの，情報探索行動全体に関わる要因 との関連を包括的にとらえた研究は見当た らない．本稿では，この眼球運動データの 分析を通じて情報探索行動の精緻な理解を 図ることを目指す。

眼球運動データを用いて，検索エンジン を対象とした情報検索における眼球運動の 分析についての研究 [7][8][9][5][10] がある
が，これらは，検索エンジンを直接的に改良 することを目的としたものが多く，眼球運 動の分析や考察においても検索エンジンの 利用部分に特化したものとなっている. 対 して本研究ではユーザ実験の方法論に即し ながらも，検索エンジンを利用した検索だ けでなく，検索結果の先にある Web ページ での利用者の探索行動をも対象とし，でき るだけ自然な状況での探索行動を観察する ことによって，より豊かなユーザ行動の理 解を得ることを目的とする .

Broder[11] は，実際のサーチエンジン利 用者調査や Web サーチエンジンのクェリ ログから , サーチェンジンの利用要求を Informational, Navigational, Transactional $の 3$ つに分類し，炎の割合などを調査している。 この 3 つの分類は光れ艺れ，Informational は Web ページの閲覧により情報の獲得を意 図した情報要求，Navigational は特定のサ イトへの移動を意図した情報要求, Transactional はウェブを介した樣々なサービスの 遂行を意図した情報要求と定義されている．

Broder によるクエリ種別がサーチェンジ ンに対する情報要求に限られているのに対 し，情報探索研究の文脈では，日常的な探 索行動における個別具体的な目的をもつた ひとかたまりののタスクとして , 作業タス ク概念の重要性も指摘されている [12] . た とえば，Kellar らは日常的な探索単位とし て，事実発見，情報収集，ブラウズ，モニ ター，トランザクションという 5 つのタス ク種別を定義している [13] .

著者らは，ユーザ実験の方法論に基づい て，2つの作業タスクを探索課題として与 えたうえで，習熟度などの点から異なると 思われるユーザ層を対象としたユーザ実験 を行い, 事前アンケート, 検索遂行中の行動 データ, 発話, 視線データ, および事後イン 
タビューといった複数の情報を収集し，分 析してきた [14][15][16][17] . 本研究では， 課題遂行中におこなわれた検索行動から得 られたクェリに対して Broder の定義にもと づく分類を行い, 分析した.これらの分析 を通じて，探索行動から得られる定量的な 情報としての視線データに対して，タスク 要因, クェリ要因, さらに検索者の属性な どとの関連を分析し, 情報探索行動の精緻 な樣相を明らかにすることを目指す . 本稿 では, 探索遂行中のサーチェンジン検索結 果ページを対象とした視線データに関する 分析結果を報告する．

\section{1 仮説}

本研究では特に, ユーザによる自然な情 報探索行動の過程を観察することにより， 情報探索プロセスにかかわる以下の要因を 挙げ, 关れ光れの要因間の関係を明らかに することを目指す．

1. ページ属性（情報を獲得する閲覧サイ 卜，閲覧ページに関する情報)

2. システム属性 (サーチェンジンの種類 , 検索アルゴリズムなど)

3. ユーザ属性 (Web 情報探索への習熟度， 検索スキルなど)

4. タスク属性 (タスクの目的, 種類など)

5. クエリ属性 (検索システム等に投入す るクエリの種類など)

ただし，本稿での分析対象がサーチェンジ ンの検索結果一覧ページ（以下，SERP と 呼ぶ）における視線データに限られるため， ページ属性を今回の分析の対象から除く. さらに検索システムに関しても，後述する ユーザ実験において観測された，Google， Yahoo! Japan , MSN の 3 つの一般的なサー チェンジンのみを対象として分析すること から , システム属性についても今回の分析 の対象から除く.
よって以下では, ユーザ属性 , タスク属 性, クエリ属性の違いが視線データに与え る影響について明らかにする．

\section{2 ユーザ実験}

\section{1 実験参加者}

学部生 11 名 (男性 5 名, 女性 5 名, 平均 年齢 20.0), 大学院生 5 名 (男性 4 名, 女 性 1 名，平均年齢 24.6) が実験に参加した。 学部生の専攻は, 経済学, 文学, 工学, 外国 語 (スペイン語学科), 心理学, 理学, 土木 工学など多樣であった . また, 大学院生は 参加者全員が図書館情報学の専攻であった．

探索実験は 2007 年 11 月 (学部生 11 名), 2008 年 3 月 (大学院生 5 名) の 2 回にわけ て実施し，実験参加者には謝金を支払つた．

\section{2 タスク}

被験者は, レポート課題と旅行課題の 2 種類の検索課題に取り組んだ .レポート課 題は,「世界史」のレポートを書くために必 要な情報を探索するという課題であった． 被験者にとって親近性のある課題とするた め，具体的なテーマは被験者自らが興味の ある対象を選んだ.一方, 旅行課題は, 身 近な人との「旅行計画」のために必要な情 報を探索するという課題であった .レポー 卜課題と同樣に, 具体的な目的地等は被験 者が興味のある場所を選んだ .

\section{3 実験手順}

被験者は事前アンケートとして, Web 検 索エンジンを用いた日常的な検索経験につ いての質問に回答した。発話練習を兼ねた 練習課題に 5 分間取り組んだ後，2つの検 索課題に光れ光れ 15 分間取り組んだ. 検 索課題は光れ光れレポート課題と旅行課題 で,順序による影響を考慮し，被験者によっ て課題の遂行順序がランダムになるよう配 置した. 


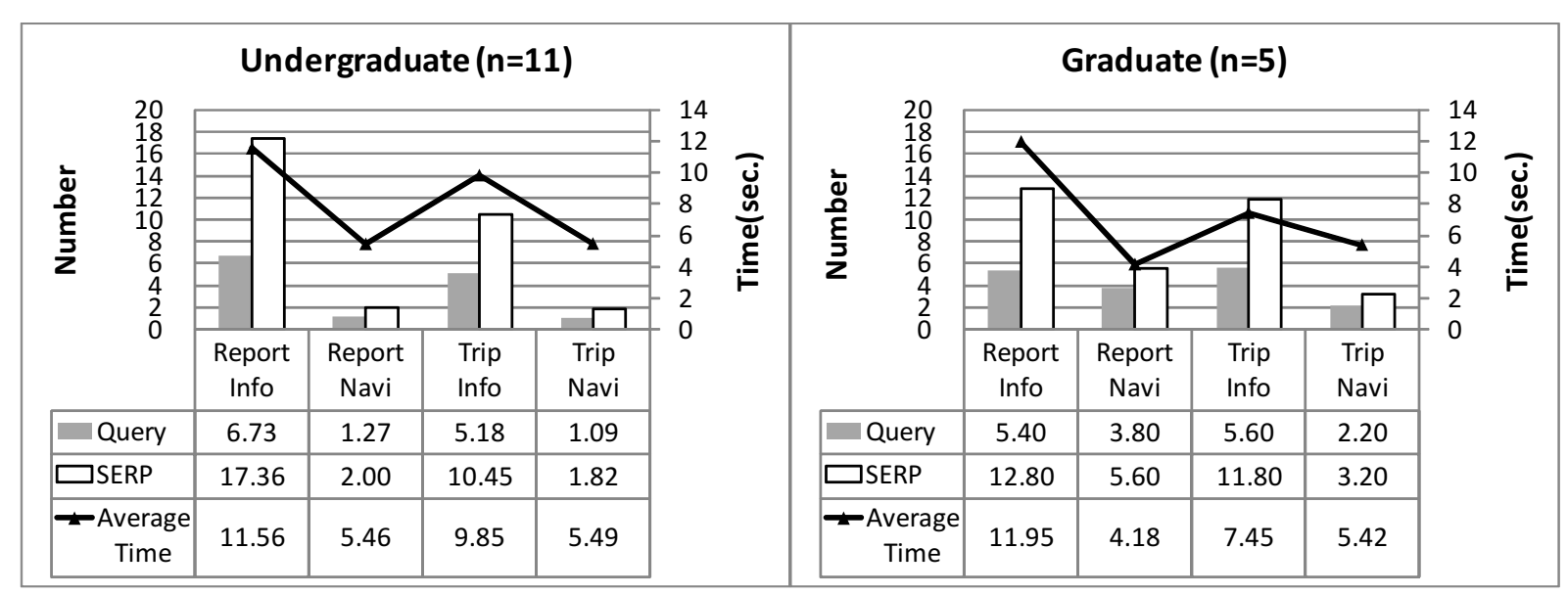

図 1 一課題あたりのクエリ数と SERP へのアクセス

\section{4 収集データ}

検索遂行中の被験者の眼球の動きは, 眼 球運動測定装置 (Voxer ST-600) によって 計測した。実験には19 インチ液晶モニタ に対し，1024×786 の解像度に設定した Windows XP の PC を使用した．Web 閲覧 用のブラウザには Firefox を使用した . ブ ラウザのブックマークには Google および Yahoo!Japan のトップページを追加し，日 常での自然な探索と同樣の状態となるよう， 自由に探索を行うよう指示した .なお，視 線データの分析のために，原則としてブラ ウザは画面上にウィンドウサイズを最大化 した状態で使用するよう促し，必要に応じ てタブ機能を使うよう指示した .また，ブ ラウザのログは Slogger, コンピュータの 画面は画面キャプチャソフト HyperCam に よって記録した . また, 課題遂行中の思考 内容を明らかにするため, 被験者には検索 遂行中に発話するよう求めた。

各課題終了後には, 課題についての困難 度や満足度等を問う事後アンケートを実施 した .さらにアンケート終了後, 課題に取 り組んでいる際の被験者の情報探索行動に ついて，インタビューを実施した．インタ ビューでは検索時の記憶想起を促すため， 画面キャプチャ映像を参照しながら進めた .

\section{3 結果}

以下では，2 章で述べた実験から獲得し たデータの分析結果を報告する .

\section{1 クエリ分類}

視線データの分析に先立ち，1.1 節で述べ たクエリ属性として, 課題遂行中にサーチ エンジンに発行されたクエリを,Broder[11] の分類にもとづき分類した .1 章で述べた ように ,Broder[11]によるクエリ分類は ,Informational, Navigational, Transactional $の 3$ つであり, Informational は Web ページに 含まれる情報の獲得を意図した情報要求， Navigational は特定のサイトへの移動を意 図した情報要求, Transactional はウェブを 介した樣々なサービスの遂行を意図した情 報要求と定義している．本研究では Broder の分類を参考にしたものの，このうち分類 が困難な Transactional クエリは採用せず， 課題遂行中に発行されたクエリを Informational クエリもしくは Navigational クェリ のいずれかに分類した . クエリ分類は著者 のうち 4 名の合議によって決定した．Informational および Navigational クエリの例 を表 1 に挙げる.表 1 によれば，レポー 卜課題の Informational クェリでは選択し 
表 1 Informational クエリ, Navigational クエリの抜粋

\begin{tabular}{|c|c|c|c|c|}
\hline \multirow{3}{*}{$\begin{array}{l} \\
\text { 学 部 生 } \\
(n=11)\end{array}$} & \multicolumn{2}{|c|}{ Report task } & \multicolumn{2}{|c|}{ Trip task } \\
\hline & Info. query & Navi. query & Info. query & Navi. query \\
\hline & $\begin{array}{l}\text { British East } \\
\text { India Company; ア } \\
\text { メリカ 起源; エリザ } \\
\text { ベート ハプスブルク } \\
\text { 系図; ケネディ リン } \\
\text { カーン; 朝鮮 鎖国; 第 } \\
\text { ニ次世界大戦 被害; } \\
\text { 三国志 歴史 }\end{array}$ & $\begin{array}{l}\text { ヒ } ト \text { ラ } \\
\text { wikipedia; } \\
\text { インド 会社 wiki; } \\
\text { msn; 清 ウィ キペ } \\
\text { ディア; ウィキペディ } \\
\text { ア; 朝日新聞; 東京エ } \\
\text { 業大学 }\end{array}$ & $\begin{array}{l}\text { 羽田 集合場所; 飛行 } \\
\text { 機; 越後湯沢; 広島 原 } \\
\text { 爆ドーム; 北海道 観光 } \\
\text { 名所; 沖縄 おすすめ観 } \\
\text { 光地; 沖縄; 沖縄 本島 } \\
\text {; 京都 イベント 花見 } \\
\text {; 摩周湖 }\end{array}$ & $\begin{array}{l}\text { 飛行機 ana; ユースホ } \\
\text { ステル; 宝塚; HIS; プ } \\
\text { リンスホテル } \\
\text { 沖縄; 京 } \\
\text { 都 市バス }\end{array}$ \\
\hline $\begin{array}{l}\text { 大学院生 } \\
(n=5)\end{array}$ & $\begin{array}{l}4750311677^{1} \text {; 仏教 } \\
\text { 成立について; ユーゴ } \\
\text { スラヴィア解体; ハワ } \\
\text { イ語 歴史; ワイマール } \\
\text { ナチス }\end{array}$ & $\begin{array}{l}\text { amazon; CiNii；八 } \\
\text { ワイ Wiki }\end{array}$ & $\begin{array}{l}\text { 東北 イベント; 屋久島 } \\
\text { みごころ; 京都 銀閣寺 } \\
\text { モデルプラン; 新幹線 } \\
\text { 料金; 四国 ホテル }\end{array}$ & $\begin{array}{l}\text { 酒田市 wiki; 屋久島 } \\
\text { JTB; 乗り換え案内; 世 } \\
\text { 羅高原ファームランド } \\
\text {; 深夜バス 四国 キラ } \\
\text { キラ }\end{array}$ \\
\hline
\end{tabular}

た世界史のトピックに近いキーワードが見 られ, Navigational クェリでは光のテーマ に関するウィキペディア上の項目や Amazon, CiNii といった別の検索サイトへと飛 ぶようなキーワードが観察された . 旅行課 題においては , Informational クェリでは選 択した行き先の地名や見どころを探すよう なキーワードとなり， Navigational クェリ では光の行き先までの交通機関のサイト名 や施設名などが現れた .

図 1 に，ユーザ種別，課題種別，クエリ 種別毎の SERP へのアクセス状況として， 一課題あたりのクエリ数 (Query), SERP 閲覧回数 (SERP), SERP 閲覧時間の平均 (Average Time) を示す.ここでクエリ数 は,サーチェンジンへクエリを発行した回 数を指す. SERP閲覧回数には, SERP 中の 次の 10 件を表示するためにページ遷移が 加わっているほか，戻るボタンなどのブラ ウザ操作によって再表示した回数も加えて いる．また，SERP 平均閲覧時間は検索結 果ページが表示されてから，別のページに 移るまでの経過時間の平均となっている .
図 1 のように得られた SERP に対するア クセス状況に対して,3 要因混合分散分析を 行った.クエリ数, SERP 閲覧回数, SERP 閲覧時間の $3 つ$ つ関していずれも,クエリ種 別要因の主効果のみが有意であった．まず クエリ数においては, Informational クエリ の方が Navigational クエリよりも有意に多 く発行された $(F(1,56)=53.35, p<.01)$. これは課題種別，ユーザ種別を問わず一 貫した傾向として観察された . SERP 閲覧 回数でも同樣の結果となった $(F(1,56)=$ $14.15, p<.05)$. また，SERP 平均閲覧時間 では,Navigational クエリにより表示された SERPの閲覧時間の方が ,Informational クエ リの場合よりも有意に短かった $(F(1,56)=$ $14.41, p<.01)$.

\section{2 眼球運動の分析}

眼球運動測定装置から得られた実験参加 者の視線データに基づく分析を以下に示す. なお，実験参加者のうち学部生 2 名は, 測 定装置の環境において視線データが得られ なかったため, 分析から除外した .

\footnotetext{
${ }^{1}$ ある参考書籍の ISBN 番号を表わす．
} 


\subsubsection{SERP Lookzone の定義}

ブラウザ操作

1: タイトルバー，2: メニュー，3: ブッ クマーク ,4: ツールバー ,5: URL バー，

6: 検索バー，7: 検索バーボタン，8: タ ブ , 12: スクロールバー，21: ページ内 検索，22: ステータスバー

SERP ページコンテンツ内

9: サービスリンク，10：クエリボッ クス，11: 検索ボタン，13: ヒット件 数, 14: スポンサーリンク , 15: スペル チェック，16: タイトル，17: スニペッ 卜 , 18: URL, 19: 関連検索，20: 次へ

図 2 SERP Lookzone

ユーザが情報探索を行う画面上のブラウ ザ操作関連の要素および SERP ページコン テンツ内の共通要素を, 図 2 に示す 22 項 目の SERP Lookzone として定義し，注視 点のタグ付けに使用した [14]．また，図 3 は SERP Lookzone の各ブロックの位置を Google の検索結果ページで示したものであ る.なおこれらの項目は今回の被験者が使 用した他のサーチェンジン (Yahoo!Japan , MSN) でも同樣に分類することができる .

次に実験時に記録した被験者の視線情報 を元に，SERP の表示が開始された時刻を 基点にして 0.5 秒間隔で画像を切り出した. 弚の上で，抽出した画像に表示された注視 点が Lookzone のいずれのに当てはまるか を人手で確認しながらタグ付けした．以下 での視線分析ではこの 0.5 秒間隔で抽出し た注視点に対する分析を行った .

眼球運動測定装置を用いた分析では一般 に，眼球運動により観察されたデータがー 定の領域に一定時間（150～500msec 程度） 停留した場合に，これを停留点として，当 該領域への注視が行われたとすることが多
い [18]．本稿での分析ではこれを用いる代 わりに，0.5 秒おきの注視点を用いるにとど めた .これは，Web 情報探索行動が非常に 迅速な情報の取捨選択をともなうものであ り，かつ，眼球運動測定の対象となる画面 のブラウザ上でのスクロールやページ遷移 行動などによって，刺激提示画面上の X-Y 軸による画一的な分析になじまず，停留点 の単位と画面上で素早く变化する注視領域 の判定を行うことが困難であるために，こ のような分析を行った . 検索結果ページの みを対象とすれば, 停留点にかかわる分析 も一定の範囲で可能であるが, 自然な状況 での情報探索を行うとの本研究の目的に沿 わないものとなる懸念から，乥の方式は採 用しなかった . 停留点分析には概して専用 ソフトウェアが必要であり，かつ，上記で 述べたような制約もあるため採用しなかっ たが，一方で一定時間間隔による注視点に 対するタグ付けは人手による労力を伴うも のの, わかりやすい Lookzone が定義され てあれば比較的容易であり，高価な専用の 分析ソフトウェアを使う必要もなく，安価 なビデオツールの組み合わせで分析できる 点に利点がある .

以下, 上記の注視ブロックとして定義し た Lookzone に対して一課題あたりどれく らいの注視があったかを示す．ただし，設 定された Lookzone のうち，実際のユーザ 実験における注視がほとんどなく，一課題 あたりの平均注視回数が 1 回に満たない 10 ブロックは分析から除外し，以下では光れ 以外の 12 ブロックの分析結果を示す.ちな みに ,この除外されたブロックとしては ,ブ

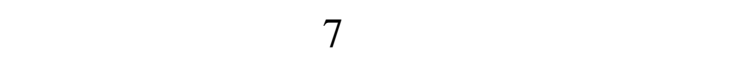
テータスバー」,「メニュー」,「URL バー」,

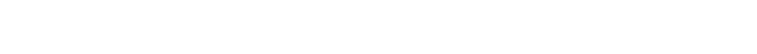
ジ内検索」）あり，SERP ページコンテンツ 


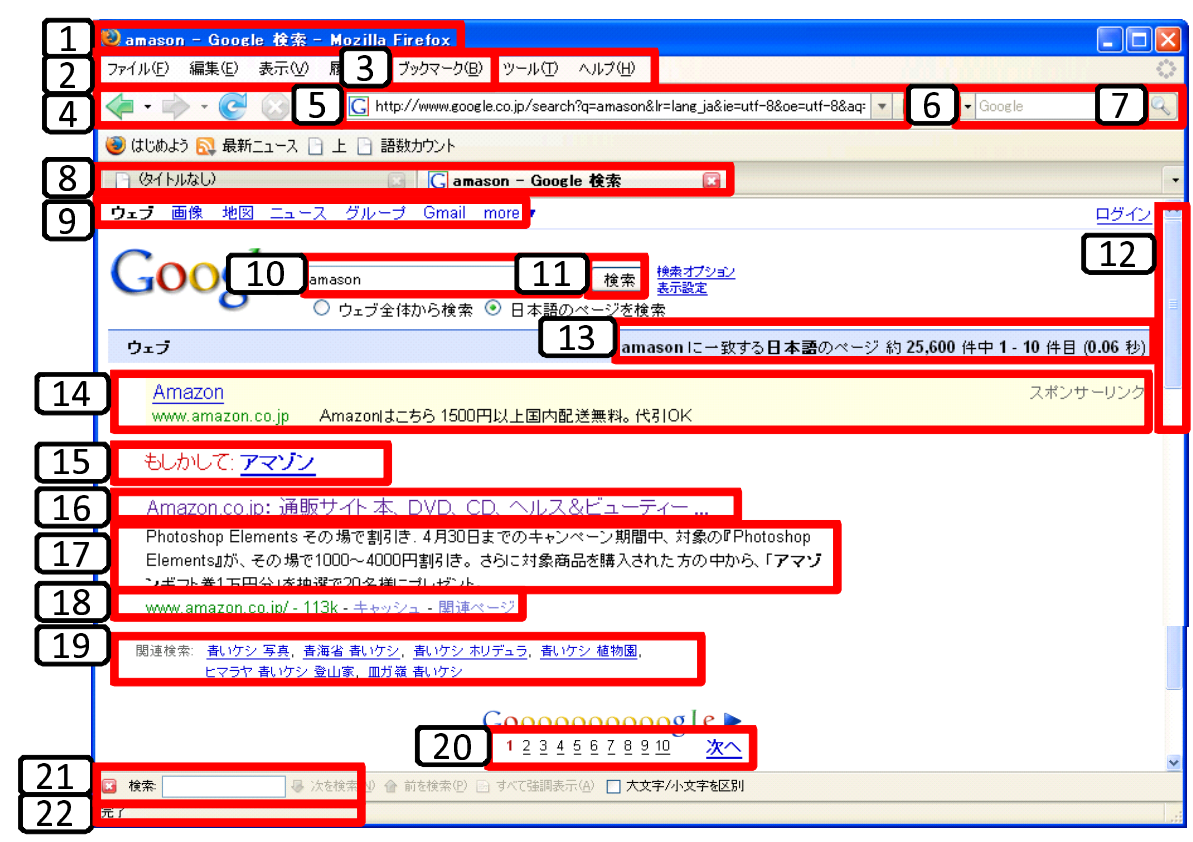

図 3 Google における SERP Lookzone の例

内要素で3つ(「次へ」,「ヒット件数」,「ス ペルチェック」) あった．つまり，たとえば， SERP 閲覧中の「スクロールバー」や「URL バー」への注視はほとんど起きなかったこ とが分かる.

表 2 に一課題あたりの各 Lookzone の注 視回数平均を示す. 表 2 からも明らかなよ うに , Lookzone として設定したブロックの うち多くは注視回数光のものが少なかった り, 全く注視を受けないブロックも多い. 一方で,「タイトル」,「スニペット」,「URL」 といった SERP において中心となる検索結 果文書の情報に関するブロックに注視が集 中していることが分かる.

表 2 に示された各 Lookzone の注視回数 に対して，3 要因混合分散分析を行った結 果を以下に示す.

ブラウザ操作関連では ,「タブ」ブロック において有意差が観察され，「検索バー」に おいて有意傾向が見られた .「タブ」では クエリ種別の主効果があり, Informational クエリによる SERP の方が Navigational ク エリの場合よりも多く「タブ」ブロックを
注視していた $(F(1,48)=6.07, p<.05)$. 「検索バー」では，学部生の場合には「検索 バー」への注視が全く見られなかった一方 で，院生では注視があった .

ブラウザ内の SERP ページ内コンテンツ のブロックでは, 「スニペット」,「タイト ル」,「URL」,「クエリボックス」,「スポン サーリンク」,「関連検索」の 6 領域で主効 果が観察された・「スニペット」では, タス ク種別とクエリ種別の交互作用に有意差が あり $(F(1,48)=7.61, p<.05)$, 下位検 定の結果，レポート・旅行課題双方におい て Navigational クエリよりも Informational クエリの場合の方が有意に多くの注視を集 め $(F(1,48)=12.04, p<.01 ; F(1,48)=$ $4.75, p<.05)$, かつ, Informational クエ リの場合にはレポート課題の方が旅行課題 よりも有意に多くの注視を集めていること が分かった $(F(1,48)=8.82, p<.05)$. 「タイトル」ではクェリの主効果があり， Informational クエリの場合の方が Navigational クエリよりも多くの注視を集めるこ 


\begin{tabular}{|c|c|c|c|c|c|}
\hline & & \multicolumn{2}{|c|}{ Report task } & \multicolumn{2}{|c|}{ Trip task } \\
\hline & & Info. query & Navi. query & Info. query & Navi. query \\
\hline \multirow{12}{*}{$\begin{array}{l}\text { 学部生 } \\
(n=9)\end{array}$} & タブ & 7.44 & 0.44 & 6.44 & 2.78 \\
\hline & 検索バー & 0.00 & 0.00 & 0.00 & 0.00 \\
\hline & タイトルバー & 3.67 & 0.11 & 0.67 & 0.33 \\
\hline & ブックマーク & 4.20 & 0.00 & 0.00 & 0.00 \\
\hline & スニペット & 87.22 & 1.56 & 31.00 & 6.00 \\
\hline & タイトル & 57.22 & 2.22 & 35.33 & 6.78 \\
\hline & URL & 36.89 & 0.44 & 12.44 & 3.11 \\
\hline & 検索ボタン & 0.56 & 0.00 & 0.67 & 0.00 \\
\hline & クエリボックス & 34.67 & 0.67 & 11.00 & 1.56 \\
\hline & サービスリンク & 16.22 & 1.11 & 5.00 & 0.11 \\
\hline & 関連検索 & 1.78 & 0.11 & 2.44 & 0.11 \\
\hline & スポンサーリンク & 4.89 & 0.11 & 9.89 & 2.56 \\
\hline \multirow{12}{*}{$\begin{array}{c}\text { 院生 } \\
(n=5)\end{array}$} & タブ & 8.80 & 3.20 & 5.60 & 0.40 \\
\hline & 検索バー & 3.40 & 3.00 & 3.80 & 0.20 \\
\hline & タイトルバー & 0.20 & 0.20 & 0.80 & 0.00 \\
\hline & ブックマーク & 0.00 & 0.00 & 0.20 & 0.00 \\
\hline & スニペット & 63.80 & 11.00 & 26.60 & 1.80 \\
\hline & タイトル & 35.20 & 6.00 & 36.60 & 2.60 \\
\hline & URL & 16.00 & 2.00 & 11.00 & 1.40 \\
\hline & 検索ボタン & 0.00 & 0.00 & 0.00 & 0.20 \\
\hline & クエリボックス & 4.00 & 1.60 & 2.00 & 1.00 \\
\hline & サービスリンク & 2.20 & 0.20 & 1.40 & 0.80 \\
\hline & 関連検索 & 1.00 & 0.20 & 1.00 & 0.20 \\
\hline & スポンサーリンク & 0.00 & 0.00 & 11.00 & 0.40 \\
\hline
\end{tabular}

とが分かった $(F(1,48)=19.96, p<.01)$. 「URL」においてもクエリの主効果があり， Informational クエリの場合の方が Navigational クエリよりも多くの注視を集めるこ とが分かった $(F(1,48)=19.43, p<.01)$. 「クエリボックス」でもクエリの主効果があ り, Informational クエリの場合に Navigational クエリの時よりも有意に多くの注視 を集めた $(F(1,48)=5.48, p<.05) .\ulcorner$ ス ポンサーリンク」においては, タスク種別 とクエリ種別双方に主効果が見られ，Informational クエリの場合の方が Navigational クエリの時よりも多くの注視を集め，か つ, 旅行課題の場合の方がレポート課題の
時よりも多くの注視を集めた $(F(1,48)=$ $8.19, p<.05 ; F(1,48)=5.74, p<.05)$. 「関連検索」ではクエリの主効果があり， Informational クエリの場合の方が Navigational クエリよりも多くの注視を集めた $(F(1,48)=7.23, p<.05)$.

\section{3 文書ランキング箇所への注視}

表 2 にも見られるとおり，SERP におい ては「スニペット」,「タイトル」,「URL」か らなる検索結果文書の要約箇所がユーザの 注目をもつとも集める領域となる．つづい て，これらの要約箇所の注視が炎れ光れの 文書ランク毎に異なるかを分析する. 要約 
箇所の領域 (前述の「タイトル」,「スニペッ $卜 」,\ulcorner\mathrm{URL}\lrcorner$ の 3 ブロック) の注視回数を まとめてランキングごとに分け，どのラン クに対する注視が多いのかをクエリ種別ご とに示す。

図 4 は, ランクごとに集計した注視回数 をランク 1 位の注視回数を 1 として正規化 したものである . Eyemark.info は Informational クエリの時の SERP 内での視点注視 回数をあらわし, Eyemark.navi は Navigational クエリにおける注視回数を示す . 今 回の実験においては, Navigational クェリ に対する SERP ではユーザは最高でもラン ク 10 位の文書への注視に留まった．対し て Informational クェリでは最大でランク 50 位の文書要約まで注視された .

\section{4 考察}

\section{1 クエリ属性}

以上に述べてきた分析結果は, SERPに おける行動の説明変数としては, 他の要因 に比べて, クェリ種別による効果が最も大 きいことを示唆するものであった .このこ とは SERP がクエリにより駆動されるとい う性質上, クエリ種別が最も直接的な影響 を与えることを考えれば，理解できる．と りわけ， Navigational クェリはサーチェン ジン上で特定のサイトの所在を探して，光 こへ到達することを目的とすることから， SERP 上でも最上位に表示された文書へと すぐに移っていく傾向が分析結果からも示 されている.たとえば, 閲覧回数・閲覧時 間の短かさや，図 4 に見られるように 1 位 もしくは 2 位，3 位へ視線が集中し，以降 の下位ランクの文書要約は注視を受けるこ とがまれであるという現象にあらわれてい る．また，SERP中の「クエリボックス」へ の視線注視で違いが出た点も, Navigational
タスクでは SERP 上でクェリの修正に時間 をかけることなどをしないという傾向を示 している．逆に Informational タスクでは． より下位ランクの文書要約までの吟味やク エリのリファインに時間をかけるといった 現象が見られた .

\section{2 ユーザ属性}

クェリ属性とは対照的に，SERP 上の注 視回数においてはユーザ属性の影響はほと んどあらわれなかった 、「検索バー」,「検 索ボタン」といったブラウザ操作機能部分 にある注視領域において，ユーザ属性の影 響がわずかながらも見られた .これは，一 般の大学学部生と图書館情報学専攻の大学 院生という属性の違いが Web ブラウザの 操作スキルに違いをもたらしたことに起因 するものと思われる . 事前アンケートの結 果によれば，大学院生群の実験参加者は全 員が日頃からタブブラウザを使用すると答 えており，一方で学部生の参加者では半数 以上の実験参加者が Internet Explorer ${ }^{2}$ を使 用していると回答しており，実際の実験に おいても大学院生の実験参加者はタブブラ ウズ機能を多用する傾向があったものの， 学部生では弚れほど見られなかった，弚う いったブラウザ操作に関する習熟度の違い が差異をもたらしたとも考えられる．たと えば , サーチェンジンの利用の際に日頃か ら検索バーを通じた検索機能を利用してい れば，自らのタスク遂行にあたって，わざわ ざサーチエンジンへページを移らずとも光 の場で検索でき，時間短縮ができると考え

\footnotetext{
2 実験を実施した 2007 年 11 月時点では, タブ ブラウザ機能を追加した Internet Explorer 7 が 公開されていたが，光の利用率は 28.9\%[19]に とどまっており, 大半の参加者はタブブラウザ 機能を持たない Internet Explorer 6 以下を使っ ていたと推測されるが，正確な常用ブラウザの バージョンに関しては確認していないため，不 明である。
} 


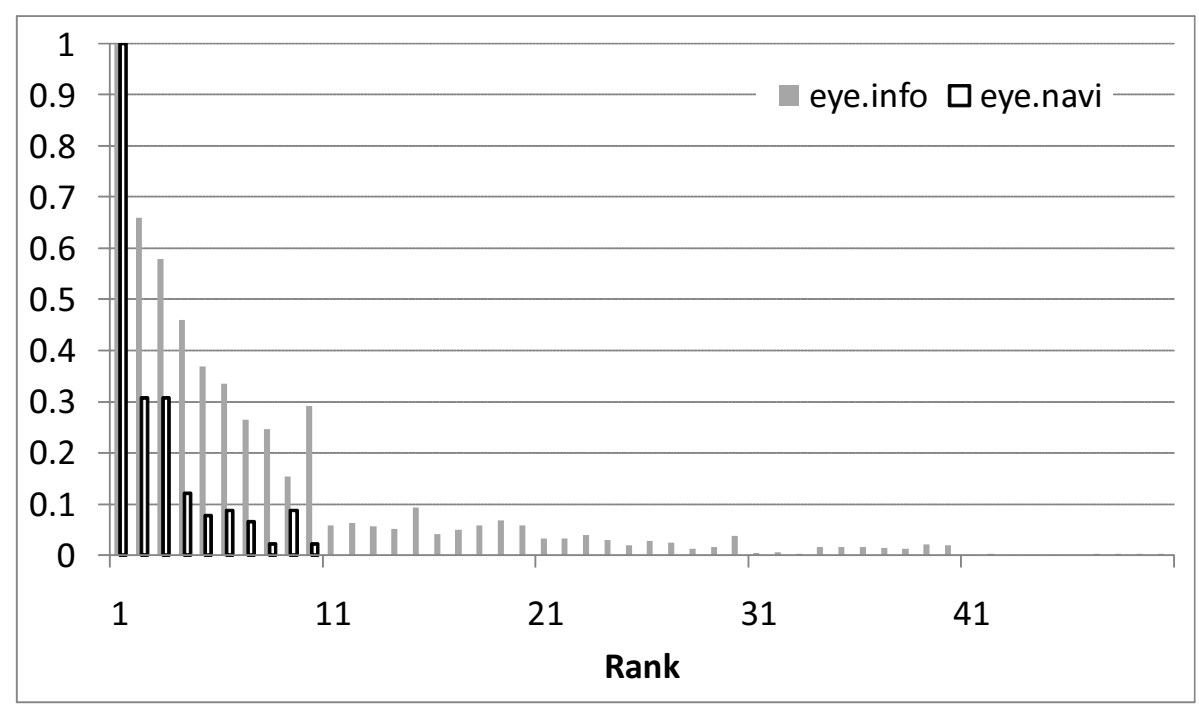

図 4 閲覧された文書要約箇所のランク毎の注視回数

たものと思われる .このようなブラウザ環 境に対する習熟が影響を与えた部分が見ら れた一方で, ユーザ属性が持つ検索スキル やWeb リソースに対する理解度の違いが与 えた箇所については, 今回分析した SERP と視線データの範囲では確認できなかった . 操作的知識に留まらないより広範なリテラ シーを情報探索においてどのように活用す るかは重要な研究課題であり, 今後, 分析 の範囲を広げて確認する必要がある .

\section{3 タスク属性}

タスク属性の影響の度合は, ユーザ属性 よりは大きいと思われるものの, 予想より も狭い範囲に留まったと言える . タスク属 性としてのレポート課題と旅行課題との違 いとして明確に見られたものは，「スニペッ 卜」および「スポンサーリンク」への注視 回数の差にとどまる．「スニペット」の場合 はレポートのための情報収集という性質か ら，ヒットした文書要約を通じて自らの情 報要求に適合するサイトであるかどうかを 読み取りながらの探索を行う傾向があった ために，旅行課題よりも「スニペット」へ の注視が集まったと考えられる．旅行とい
うタスクの性質から，「スポンサーリンク」 に広告として掲載されるリンク先が重要な 情報源となることもありうるとも思われる . また一般に，サーチェンジン上でも多くの 「スポンサーリンク」が表示されることも原 因の一つと思われる . 旅行 ・ 観光業界はも ともと広告費の多い業種であり，インター ネット広告の大手代理店サイバー・コミュ ニケーションズによれば, 2007 年第 4 四半 期における交通・レジャー業種の広告売り 上げは全体の構成比 $8.4 \%$ であり，全 17 業 種の分類中でも「金融・保険」「情報・通信」 「不動産・住宅設備」に次いで 4 番目に売り 上げの多い業種である [19, p.59] . ただし， スポンサーリンク注視がこのような出稿量 の多さによって生起されたものであるか， むしろユーザにとって欲しい情報が提供さ れた結果によるのかについては，本稿では 分析に至っていない.

また，今回設定した 2 課題はいずれも Kellar ら [13] によるタスク種別の定義によ れば，情報収集タスクにあたるものと見る こともでき, 弚の点では, タスク自体がさほ どの違いを生むような要因となっていない とも考えられる．ただし，以前の分析 [15] 
から SERP に限らないWeb 全体を使った閲 覧パターンでは, 旅行課題の方がレポート 課題よりも閲覧ページ数が多く，すばやい 情報収集をしているなどといった違いがあ ることが分かっている.このような違いが タスク種別关のものの違いと言ってよいの か，もしくはタスクに特有の探索方略や炎 のための問題解決空間の構造として現われ ているのか, とりわけ，これらタスクの特 性产のものを検討していくことが今後必要 となると思われる . 今後の課題としたい.

\section{5 おわりに}

本稿ではサーチェンジン上の SERP にお いて, ユーザ属性, タスク属性, クエリ属 性の違いという 3 要因が視線データに与え る影響について分析した.SERP に対して 直接的な関係となるクエリ属性としてとら えた Informational/Navigational のクエリ種 別が SERP ユーザ行動の説明変数として大 きな影響を与えていることが分かった . タ スク属性およびユーザ属性は比較的少数の 変数との関係が見られるにとどまり, SERP および視線データに限っては，広範な影響 を与える変数ではないことが示唆された .

著者らは, 探索型情報検索のためのユー ザの情報探索行動を理解するための研究開 発に取り組んでいる.情報探索行動にかか わる精緻な分析のために, 今後は分析の範 囲を広げ, 探索のプロセスや探索時のモー ド切り替えなど, より大きな研究課題との 相関を探ることが今後の課題である .

\section{謝辞}

本研究は国立情報学研究所公募型研究「情 報探索行動の認知モデルの構築と炎の応用 に関する研究」の支援を受けた .

\section{参考文献}

[1] Spink, Amanda; Jansen, Bernard J.: "Web Search: Public Searching of the Web". Kluwer Academic Publishers, Dordrecht, Netherlands, 199p., 2004.

[2] Terai, Hitoshi; Miwa, Kazuhisa: "Sudden and Gradual Processes of Insight Problem Solving: Investigation by Combination of Experiments and Simulations", Proceedings of 28th Annual Meeting of the Cognitive Science Society, pp. 834-839, 2006.

[3] Jacob, Robert J. K.; Kari, Keith S.: "Eye tracking in human-computer interaction and usability research: ready to deliver the promises (section commentary)". Hyona, Jukka; Radach, Ralph; Deubel, Heiner, editors, The mind's eye: cognitive and applied aspects of eye movement research, pp. 573-605. Elsevier Science, Amsterdam, 2003.

[4] Nielsen, Jakob: "Eyetracking Research into Web Usability". URL: http: / / www.useit.com/eyetracking/ (2009 年 4 月 10 日参照) .

[5] Granka, Laura A.; Joachims, Thorsten; Gay, Geri: "Eye-tracking analysis of user behavior in WWW search", SIGIR '04: Proceedings of the 27th annual international ACM SIGIR conference on Research and development in information retrieval, pp. 478-479. ACM, 2004.

[6] Joachims, Thorsten: "Optimizing search engines using clickthrough data", Proceedings of KDD 2002, pp. 133-142. ACM, 2002. 
[7] Lorigo, Lori; Haridasan, Maya; Brynjarsdottir, Hronn; Xia, Ling; Joachims, Thorsten; Gay, Geri; Granka, Laura; Pellacini, Fabio; Pan, Bing: "Eye tracking and online search: Lessons learned and challenges ahead", JASIS\&T, Vol. 59, No. 7, pp. 1041-1052, 2008.

[8] Lorigo, Lori; Pan, Bing; Hembrooke, Helene; Joachims, Thorsten; Granka, Laura; Gay, Geri: "The influence of task and gender on search and evaluation behavior using Google", Inf. Process. Manage., Vol. 42, No. 4, pp. 1123-1132, 2006.

[9] Guan, Zhiwei; Cutrell, Edward: "An eye tracking study of the effect of target rank on web search", $C H I$ '07: Proceedings of the SIGCHI conference on Human factors in computing systems, pp. 417-420, New York, NY, USA, 2007. ACM.

[10] Pan, Bing; Hembrooke, Helene; Joachims, Thorsten; Lorigo, Lori; Gay, Geri; Granka, Laura: "In Google we trust: Users' decisions on rank, position and relevancy", Journal of Computer-Mediated Communication, Vol. 12, No. 3, pp. 801-823, 2007.

[11] Broder, Andrei: "A Taxonomy of Web Search", SIGIR Forum, Vol. 36, No. 2, pp. 3-10, 2002.

[12] Ingwersen, Peter; Jävelin, Kalervo: "The Turn: Integration of Information Seeking and Retrieval in Context". Springer, 448p., 2005.

[13] Kellar, Melanie; Watters, Carolyn; Shepherd, Michael: "A field study characterizing Web-based information- seeking tasks", Journal of the American Society for Information Science and Technology, Vol. 58, No. 7, pp. 9991018, 2007.

[14] 高久雅生; 寺井仁; 江草由佳; 齋藤ひと み; 三輪眞木子; 神門典子: 「Web 情 報探索における視線データの予備的分 析」, 情報知識学会誌, Vol. 18, No. 2, pp. 181-188, 2008.

[15] Terai, Hitoshi; Saito, Hitomi; Egusa, Yuka; Takaku, Masao; Miwa, Makiko; Kando, Noriko: "Differences between informational and transactional tasks in information seeking on the web", Proceedings of IIiX 2008, pp. 152-159. ACM, 2008.

[16] 齋藤ひとみ; 江草由佳; 高久雅生; 寺井 仁; 三輪眞木子; 神門典子: 「Web 情 報探索行動の分析: 課題の志向性と経 験の違いによる影響についての予備 的検討」, 電子情報通信学会研究報告 $\ulcorner$ Web インテリジェンスとインタラク ション」研究会 (IEICE SIG-WI2) 第 13 回研究会, pp. 37-42, 2008.

[17] Egusa, Yuka; Takaku, Masao; Terai, Hitoshi; Saito, Hitomi; Kando, Noriko; Miwa, Makiko: "Visualization of User Eye Movements for Search Result Pages", Proceedings of EVIA 2008 (NTCIR-7 Pre-Meeting Workshop), pp. 42-46, 2008.

[18] 斎田真也: 「読みと眼球運動」。『眼 球運動の実験心理学』. 第 8 章, pp. 167-197. 名古屋大学出版会, 名古屋, 1993.

[19] 財団法人インターネット協会監修:「イ ンターネット白書 2008」. インプレス R\&D, 東京, 368p., 2008. 